\title{
Література:
}

1. Власенко О. М. Проблема формування моральних цінностей майбутніх учителів у теорії і практиці професійної освіти. Освіта Донбасу. 2004. № 3 - 4. С. 87 - 93.

2. Степанов О. М., М. М. Фіцула. Основи психології і педагогіки: навч. посібник. 2-е вид., випр., доп. К.: Академвидав, 2005. 520 с.

DOI https://doi.org/10.30525/978-9934-26-173-2-27

\section{ПРОФЕСІЙНЕ ВДОСКОНАЛЕННЯ: УНІВЕРСИТЕТСЬКИЙ ПРОСТІР}

\author{
Голос Г. А. \\ доктор філософії, \\ стариий викладач кафедри германської філологї \\ Київський університет імені Бориса Грінченка \\ м. Київ, Україна
}

Постановка проблеми. У XXI столітті проблема формування фахівця важко вирішується без продуктивного партнерства усіх учасників освітнього процесу. Все більше постає розуміння важливості налагодження такої взаємодії між здобувачами і викладачем, що дефакто часто подібне до традиційних «знаннєнакопичувальних» практик. Проблема, яку висвітлює стаття: співтворчість, партнерство, взаємодія студентської молоді і викладача - незмінні константи плідного навчаннявикладання у вищій школі, джерело обопільного впливу учасників освітнього процесу один на одного в контексті професійного росту.

Стан дослідження. Теоретичні аспекти професійного становлення фахівця, професійного вдосконалення педагога розкрито у публікаціях зарубіжних і вітчизняних науковців: висвітлено психологічно-педагогічні аспекти професіоналізації особистості, проаналізовано проблеми професійного самовизначення особистості, виокремлено етапи професійного становлення, подано досвід професійного становлення майбутніх фахівців у різних закладах вищої освіти (A. Glatthorn, D. Schon, Л. Долинська, Л. Жовтан, О. Мазко, О. Пісоцька, О. Савченко) $[1 ; 2 ; 4 ; 5 ; 7 ; 8 ; 9 ; 10]$. Серед широкого спектру проблем професійного вдосконалення, що піднімаються авторами, недостатньо висвітленою залишається феноменологія взаємовпливу викладач-студент, що спонукає до пошуку нових практик професійного вдосконалення. 
Виклад основних положень. Забезпечення якісної професійної підготовки кваліфікованих фахівців на засадах партнерства є наскрізною тезою в освітній політиці практично усіх сучасних педагогічних систем (рекомендації OECD, Закон України «Про освіту») [3; 9]. В університетському просторі взаємодія викладача і студентів розглядається широко, зокрема, як співробітництво носіїв культурних та духовних цінностей, рефлексивність яких сприяє формуванню взаєморозуміння та узгодженості дій партнерів у процесі сумісної діяльності [5, с. 7].

Особливої актуальності викладацько-студентське партнерство набуває у роботі із «сильною», мотивованою студентською молоддю, прикметними рисами якої $\epsilon$ : високий рівень критичного мислення, уміння навчатися, ініціативність, самостійність, креативність, розуміння власної персональної і професійної траєкторії росту. На практичних заняттях така молодь охоче виступає як «надавач» нової, додаткової (до навчального контенту) інформації, 3 ентузіазмом ставиться до навчальних «викликів». 3 метою утримання студентської мотивації, попередження психологічного напруження в колективі, викладач має відійти від усталеної, «ритуальної» методики викладання, усіляко удосконалювати професійну майстерність свою і своїх учнів.

Досвід роботи 3 талановитою молоддю на заняттях $з$ практики усного і писемного мовлення доводить популярність у здобувачів, зокрема, й таких видів діяльності: обговорення (новин, подкастів, історій з життя, суперечливих тем); вправ на розвиток критичного мислення (аналітичне читання, вправи на знаходження причинно-наслідкового зв'язку), делегування викладачем своєї ролі студентам (нова тема розбивається на підтеми, студенти самостійно готують різні види діяльності для опанування нової лексики із одногрупниками, використовуючи розмаїття цифрових інструментів), творчі проєкти (оманлива фонетика, робота у малих групах) тощо.

Висновки. Професійне становлення фахівця у вищій школі, підтримки професійного тонусу викладача - складний, динамічний, взаємообумовлений процес. Визначальну роль у ньому відіграє співпраця всіх учасників освітнього процесу, їі якість. Впровадження продуктивного викладацько-студентського партнерства $є$ безумовно потрібною формою організації діяльності в контексті компетентнісної педагогіки, що потребує подальшого висвітлення та аналізу успішних практик. 


\section{Література:}

1. Долинська Л. В. Діалогічність як умова ефективної педагогічної взаємодії викладача зі студентом // Наука і освіта. № 3. 2008. С. 143-145.

2. Жовтан Л. В. Організація взаємодії викладача й студентів як рівноправних суб'єктів педагогічного процесу // Вісн. Луган. нац. ун-ту ім. Т. Шевченка. Пед. науки. № 4, ч. 1. 2012. С. 81-89.

3. Закон України «Про освіту». URL: https://zakon.rada.gov.ua/ laws/show/2145-19

4. Мазко О. П. Інтерактивні технології формування культури педагогічної взаємодії майбутнього вчителя іноземних мов. Житомир: Вид-во ЖДУ ім. Івана Франка, 2014. 96 с.

5. Пісоцька О. О. Виховання культури взаємодії викладачів і студентів в університетському освітньо-виховному просторі: автореф. дис. ... канд. пед. наук. Східноукр. нац. ун-т ім. В. Даля. Луганськ, 2010. $20 \mathrm{c}$.

6. Савченко О. П. «Викладач - студент»: суть і особливості процесу спілкування // Наука і освіта. № 4. 2011. С. 362-364.

7. Bar-Yam M., Rhoades K., Booth Sweeney L., Kaput J., Bar-Yam Y. Complex Systems Perspectives on Education and the Education System. New England Complex Systems Institute. URL: https://necsi.edu/changes-in-theteaching-and-learning-process-in-a-complex-education-system

8. Glatthorn. A. Cooperative professional development: Peer-Centered options for Teacher Growth. Educational Leadership. 1987. Vol. 45, P. 31-35

9. OECD Future of Education and Skills 2030. URL: https://www.oecd.org/education/2030-project/

10. Schön D. The Reflective Practitioner: How Professionals Think in Action. URL: https://www.academia.edu/36335079/Donald_A_Sch\% C3\%B6n_The_Reflective_Practitioner_How_Professionals_Think_In_Actio n_Basic_Books_1984_pdf 